\title{
A Material History of Electroshock Therapy
}

\author{
Electroshock Technology in Europe until 1945
}

\author{
Lara Rzesnitzek and Sascha Lang
}

The article considers the history of electroshock therapy as a history of medical technology, professional cooperation and business competition. A variation of a history from below is intended; though not from the patients' perspective (Porter, Theory Soc 14:175-198, 1985), but with a focus on electrodes, circuitry and patents. Such a 'material history' of electroshock therapy reveals that the technical make-up of electroshock devices and what they were used for was relative to the changing interests of physicians, industrial companies and mental health politics; it makes an intriguing case for the Social Construction of Technology theory (Bijker et al., The social construction of technological systems: new directions in the sociology and history of technology. MIT Press, Cambridge, MA, 1987).

Keywords: History of psychiatry, history of electroconvulsive therapy, shock therapies, convulsive therapy, National Socialism

Eine Geschichte der Elektroschocktherapie ,von unten'. Elektroschocktechnologie in Europa bis 1945

Der Artikel nimmt die Geschichte der Elektroschocktherapie aus der Perspektive der Medizintechnik in den Blick. Eine neue Sichtweise einer Geschichte ,von unten' wird ausprobiert, allerdings nicht im Sinne einer Darstellung der Therapie aus der Patientensicht (Porter, Theory Soc 14:175-198, 1985), sondern einer Analyse der Einführung der Elektroschocktherapie anhand von Detailformen der entwickelten Geräte, ihrer Elektroden, technischen Verschaltungen und durch sie ausgelösten Patentstreitigkeiten. Solch eine , materielle' Geschichte der Elektroschocktherapie zeigt, dass das technische Design der Elektroschockgeräte und wofür sie genutzt wurden, relativ zu den jeweiligen Interessen beteiligter Ärzte, Kliniken, Firmen wie auch Gesundheitspolitik war; sie erweist sich als ein bemerkenswertes Beispiel der These der Social Construction of Technology (Bijker et al., The social construction of technological systems: new directions in the sociology and history of technology. MIT Press, Cambridge, MA, 1987).

Schlüsse/wörter: Geschichte der Psychiatrie, Geschichte der Elektrokrampftherapie, Schocktherapie, Konvulsionstherapie, Nationalsozialismus 


\section{Writing the History of Electroshock Therapy 'From Below'}

The history of electroshock therapy has already been reviewed several times. Intellectual histories, social histories and entangled histories were written about it.

'Histories of ideas' of electroshock therapy analyzed the concept of 'electricity' as a healing or disciplinary method for war neuroses of soldiers during World War I, or they studied the notion of therapeutic epileptic convulsions and "electroshock" as further "shock therapy" (Kalinowsky 1986; Endler 1988; Berrios 1997; Shorter \& Healy 2007). The gap to a social history of electroshock therapy was bridged with Thomas Szaz' article "From the Slaughterhouse to the Madhouse" that provided an analysis of the situation of the first trial of electroshock therapy in the Psychiatric University Clinic in Rome besides its provocative claim that the idea of the electroshock method had stemmed from electric slaughtering (Szaz 1971). Further social histories described the application of shock treatment in daily hospital practice in the USA (Braslow 1997), others in Europe during the time of National Socialism (Siemen 1999; Bueltzingsloewen 2010; Schmuhl \& Roelcke 2013). Within a more complex perspective, the international diffusion of shock therapies in general and electroshock treatment in particular was especially analysed relative to the forced migration of physicians of Jewish origin or faith (Peters 1992; Rzesnitzek 2013, 2015a).

However, a material history of electroshock therapy in terms of a history from below with a focus on screws, electrodes, circuitry and patents still remains a desideratum. With this article we aim to write a history of the medical electroshock therapy technique with its changing electric wirings, electrodes and handlings by applying the Social Construction of Technology (SCOT) theory, which assumes that any technology is determined by contingent social factors (Bijker et al. 1987).

The process of the invention and early diffusion of electroshock therapy in the late 1930s and early 1940s depended strongly on circumstances in medical technology, sales strategies and patents; in sum, a special device design was only a single point in the large field of technical possibilities, reflecting the interpretations of certain relevant actors, among them physicians, technicians and industrial companies. In this line, we use private correspondences and non-official reports of technicians and physicians providing an insight into the various, partly professional, partly political or economic interests involved as a first step in our analysis.

The German company Siemens played a crucial role in introducing the technical process. Sources concerning the patent history of the electroshock apparatuses found in the company's Archive for Medical Technology (Unternehmensarchiv für Medizintechnik) are used in a second step to illustrate 
how conflicting economic interests and consecutive legal regulations influenced the clinical introduction of electroshock therapy. In keeping with the Social Construction of Technology (SCOT) concept of "design flexibility", the analysis of the sources demonstrates how the specific conditions of National Socialism in Europe and resulting changes in patent law as well as the requirements of World War II repeatedly changed and formed the technical details of the electroshock apparatus, deciding which design was considered most suited for clinical use. As a matter of fact, in the case of electroshock therapy, the social process shaping the technique was so adaptable that it turned a therapeutic technique into a method for "euthanasia" killings.

The analysis of the technical aspects of the introduction of electroshock therapy with the different apparatuses developed and the related disputes about patents and sales, therefore enriches and changes not only the understanding of the history of electroshock therapy, but provides an example of a new material history of medical practices (Hess 2000; Hess \& Mendelsohn 2014).

\section{The Italian Apparecchio per l'elettroshock}

The first electroshock apparatus was developed in Rome. Against the backdrop of longstanding research on epilepsy, Ugo Cerletti (1877-1963) had entrusted his technically versed assistant doctor Lucio Bini (1908-1964) with animal studies on examining the possibility of safely causing epileptic seizures with electricity. In contrast to the pharmacological induction of epileptic seizures in patients, it promised to be simpler, more reliable and cheaper (Berrios 1997). In this line electroshock was just a variation of the 'convulsive therapy' that the Hungarian Ladislav Meduna (1896-1964) had proposed based on the hypothesis of an antagonism of schizophrenia and epilepsy (Meduna 1937).

First results of tests in dogs with an apparatus designed by Bini were given in May 1937 on the occasion of the international conference "The Therapy of Schizophrenia-Insulin Shock, Cardiazol, Permanent sleep” in Switzerland. The trials on patients of the Roman Clinic were presented at the Royal Medical Academy in Rome in May 1938, and published in Italian professional magazines as "electric shock" ("l'elettroshock"). The method was geared to initially applying a weak calibration current to two electrodes fixed at the patient's head with a special supporting structure to measure the so-called head resistance. On the basis of this value, the suitable level of voltage could subsequently be selected so that the electricity flowing through the patient's head via the same electrodes for fractions of a second would cause an epileptic seizure. 
Given that Meduna's convulsive therapy was also called "shock therapy"; a name most widely used for Manfred Sakel's insulin coma therapy (Sakel 1935), the denomination "electroshock" was intuitive (cf. Sogliani 1939).

Although the shock paradigm was one of the oldest therapeutic concepts of psychiatry as a medical discipline (Reil 1808), the shock therapies of the 1930s were mostly assumed to have a distinct therapeutic mechanism compared to the more general impact of the swivelling chair or the cold showers of the nineteenth century (Braunmühl 1941). While insulin coma and pharmacological convulsive therapy were mostly discontinued in Europe during the late 1950s and only continued in few places until the 1970s (Rzesnitzek 2015b), electroshock therapy or electro-convulsive therapy still is a recommended therapy in severe depression and catatonia (Grözinger et al. 2012); its technical equipment purchased mostly from a US company (Abrams 2002).

The first company licensed to produce Bini's first electroshock model exclusively was the Milanese company Officine Elettrotecniche Italiane Ing. Vittorio Arcioni S.a.s. (Arcioni). Advertising brochures and manuals printed in 1939 were titled "Apparecchio per l'elettroshock—brevetto Prof. Bini”. Bini had applied for a patent on the electric installation of his apparatus. In Italy, his application from October 1938 was granted in March 1939 naming him as the sole inventor of the apparatus (Fig. 1). ${ }^{1}$ One month later Bini also approached the French patent office, which provided him in early December 1939 with a property right to the circuit of the apparatus under the name "Appareil pour applications électriques". ${ }^{2}$ In July 1939 Bini moreover applied for protection of invention at the Deutschen Reichspatentamt for his "electric healing device for generating convulsions". 3

However, the "ground-breaking method" still met with restraint: "Despite all ingenuity, the technical side of the problem did not seem to have been solved sufficiently" (Selzer 1939). Max Müller (1894-1980), who had organized the Swiss conference on the pharmacological shock therapies, remembered clearly:

After Bini's lectures, there were still some smaller publications from the Roman Clinic and Italian clinics that did, however, hardly attract any interest either. In addition, another difficult factor was that the apparatus developed by the Italians was a trade secret of company Arcioni in Milan and only difficult to get so that nobody was keen on this apparently risky and still little tested method (Müller 1982: 246).

Nevertheless, Max Müller was to apply the electroshock technique for the first time outside of Italy and launch it in Switzerland. A promotional visit and a letter from the Italian clinic, paid for and written by Lothar Kalinowsky (18991992), a German emigrant of Jewish origin, encouraged him to undertake this step (cf. Rzesnitzek 2013, 2015a).

In implementing electroshock at Cerletti's clinic the Berlin neurologist Kalinowsky had been in charge of observing the "neurological changes during 


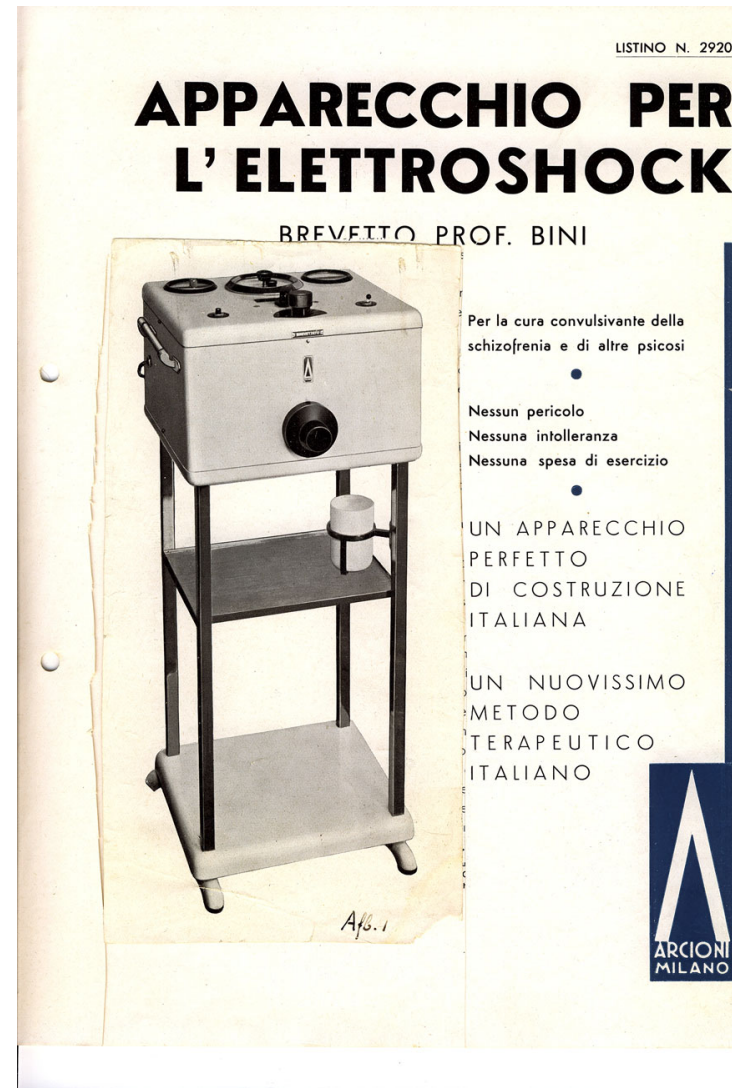

Fig. 1 Italian manual Apparecchio per l'elettroshock-brevetto Prof. Bini 1939 (Collection Dolhuys, museum van de geest, Haarlem, The Netherlands)

and after the seizure" (Kalinowsky 1977: 154). Kalinowsky had relocated to Italy after losing his prior position at the psychiatric hospital of the Charite in Berlin due to the Law for the Restoration of the Professional Civil Service (Gesetz zur Wiederherstellung des Berufsbeamtentums) passed by the National Socialists on 7 April 1933. As Kalinowsky's position at Cerletti's clinic was unpaid, the prospect of receiving a financial income via his silent partnership in Bini's patents, played a role in Kalinowsky's commitment towards Max Müller. Even though the capital of his wife allowed a certain lifestyle, Kalinowsky had to generate an income for his family of four. So it was on Kalinowsky's advice, Max Müller later remembered in his autobiography, that he ordered the "apparecchio per l'elettroshock" from Arcioni with the start of World War II, and started first treatments in November 1939 (Müller 1982: 246). ${ }^{4}$

With the equipment acquired from Arcioni, electroshock therapy ("l'elettroshock") was also introduced in French-speaking Switzerland early on (Forel 1941). The fear that Italy's entry into the war would create a bottleneck 
in the supply prompted Müller to transfer the further technical development to Switzerland, thus providing the Swiss company Purtschert \& Co. in Luzern his Arcioni apparatus and ordering its reproduction (Müller 1982: 247).

\section{Diffusion of Electroshock: The Role of Lothar Kalinowsky}

The introduction of the pharmacologic shock therapies-such as insulin coma' and 'cardiazol convulsive' therapy-must be considered within the context of the forced emigration of doctors and scientists of Jewish faith or descent due to National Socialism (Peters 1992). And the same applied to the introduction of electroshock, made particularly evident by the impact Kalinowsky had on this process (Rzesnitzek 2013).

Following the aggravation of Italian racial laws in the wake of Pact of Steel, formally known as the Pact of Friendship and Alliance between Germany and Italy, signed between Fascist Italy and Nazi Germany on 22 May 1939, the diplomas of doctor's of foreign "non-Aryans" were annulled. That deprived Kalinowsky of his professional and economic livelihood, forcing him into another exile via France, the Netherlands, England, and finally to the USA.

Bini and Cerletti were quite interested in taking the method abroad, so Bini provided Kalinowsky with the plans of his apparatus on the trip to Paris and Holland (Abrams 1988: 32). Proving rumours wrong that he had lost the plans en route to Paris (Müller 1982: 247), Kalinowsky delivered them to the renowned French medical technology engineering company Duflot as previously agreed with Henri Claude (1869-1945), the former medical director and chair of the University Hospital Sainte Anne. ${ }^{5}$ Obviously progress in the production took some time in materialising. Kalinowsky wrote to his friend and business partner Bini on 26 May 1940 in Italian:

Since the start of the war they haven't done anything in Paris. I sent one letter after the other and finally learnt that Henri Claude's clinic has been closed down. Company Duflot of all things-builder of the first apparatus for the clinic and company of highest rank-now wrote to me that Prof. Claude wants to continue in some places despite the war. In a very energetic letter I replied that I forbid the construction of any other apparatus by all means until they have sent the signed contract to our percentage. I doubt that they will sent it to me because if there will be war between Italy and France, they would not have to pay anymore. ${ }^{6}$

Kalinowsky thus accused Duflot of turning France into the only country not to introduce the method for widespread use, despite the fact that it promised enormous savings for hospitals especially during the war. At the same time Kalinowsky agreed with Bini to decrease the patent fee from 20 to 15 per cent of the sales price so as to create another incentive for Duflot to sign the contract; this, however, was never achieved. 
These debates and not just the alleged "difficulty of procuring an original apparatus on the market", had finally brought about the decision of French psychiatrists to construct a new "French" apparatus of their own: the Sismothère produced by Service Radiologique J. Chillaud. The first tests for that apparatus performed on dogs were presented by Marcel Lapipe, from Hospital Vaugirard, and Jean Rondepierre, psychiatrist at Hospital Ville Evrard on the outskirts of Paris, on the occasion of the meeting of the Societé Médico-Psychologique on 28 April 1941 (Lapipe \& Rondepierre 1941). In 1942 another French apparatus with a new technical principle, namely the usage of direct current instead of alternating current, was invented by Paul Delmas-Marsalet, professor of psychiatry in Bordeaux; the apparatus was manufactured in Bordeaux by Solex and patented in France. ${ }^{7}$

Kalinowsky also helped to introduce electroshock therapy in the Netherlands; here, however, with an Arcioni device that had been delivered directly from Italy (Barnhoorn 1940: 292). After reading the first article by Cerletti and Bini, the medical director of the small Dutch psychiatric institution Sint Willibrordusstichting in Heiloo, Johannes Anthonius Joseph Barnhoorn, had contacted Cerletti and ordered an Arcioni apparatus. In April 1939, Arcioni sent the order confirmation with an invoice for the "apparatus for electroshock, patent of Prof Bini” (de Valk 2009). Arriving at Heiloo in July 1939, Kalinowsky was able to teach the electroshock method using that apparatus (Rzesnitzek 2013).

Not even the beginning of World War II could prevent Kalinowsky from selling electroshock therapy. In England, it was the Solus Electric Company, which he advised to build an apparatus according to Bini's plans (cf. Rzesnitzek 2015a). Psychiatrists of the Warlingham Park Hospital were the first ones to use this Solus apparatus - the "Bini patent"-as they explicitly noted, publishing the results with acknowledgments to Kalinowsky (Shepley \& McGregor 1939).

The terrain of the new therapy and its apparatus was already highly competitive in England. In late 1939, another apparatus came into use that had been commissioned by Frederick Golla (1877-1968) and William Grey Walter (1910-1977) from Edison Swan Electric's (Flemming et al. 1939). When the renowned Royal Society of Medicine invited for a session in January 1940 dedicated to "electrically induced convulsions", invitee Kalinowsky reported on the two-year experience with Bini's apparatus in order to convince the audience to acknowledge the English patent Lucio Bini and he had applied for. However, his efforts directed against Walter and Golla finally failed (Anonymous 1940). Walter, a renowned expert in the area of electroencephalography, was a strong rival, who, in his cooperation with Golla, endangered the prospect of Bini's patent to become the standard of electroshock devices as they signalled doubts as early as 1940 whether the sine wave alternating current Bini had chosen really represented the best possible stimulus form (Golla et al. 
1940). What Kalinowsky was particularly concerned about was a modification already carried out by Walter and his colleagues: a change of the electrode construction that they demonstrated in a film at the meeting of the Royal Society of Medicine. The electrodes were fixed at the head of a female patient by means of elastic bands (Anonymous 1940: 105), in contrast to Bini's electrode-forceps or clip construction, which was a genuine part of his apparatus and patent.

Especially the issue of the altered electrode construction continued to worry Kalinowsky as can be discerned from his letters to Bini from his New York exile:

In England, the patent has not yet been accepted. I have written you about the history of the apparatus by Grey Walter. The "Solus" apparatus they have built with me on the basis of the contract (see the works by Shepley, Mc Gregor) now costs just as much as the apparatus by Arcioni. [...] The apparatus built under Grey Walter, costs half as much but I cannot do anything as long as the patent has not been accepted. With reference to it, I would like to ask you for a critical and exact description of this apparatus, which could serve me for proving that the apparatus has its disadvantages [...]: they do not start by determining the voltage they want to give but immediately define the milliampere for the treatment. They do not even use a special electrode. So I ask you to inform me about the details of their method and explain to me what I never really understood: Why have you used such a large electrode? (To avoid burnings? To reach a larger area of the brain?) ${ }^{8}$

Kalinowsky's considerations illustrate that he and Bini had indeed an eye on the market situation and feared a more economical competitor. Yet it also shows how little Kalinowsky was privy to the considerations for the construction of the apparatus. One month later (17 June 1940), Kalinowsky still urged Bini to provide technical arguments against the unwanted English competitor so that he could say "something against this model when it comes to advertising to colleagues!"

Kalinowsky's "advertising" technique proved successful: the renowned clinical research department of the Columbia University, the New York Psychiatric Institute, where Kalinowsky was already allowed to accompany the studies on electroshock therapy at that time (cf. Rzesnitzek 2015a), exchanged the first apparatus built according to the model by Walter for one manufactured according to Bini's plans. Although it had also been Bini's Arcioni construction that had been used for the very first electroshock treatments in the USA, due to the fact that another exiled assistant of Cerletti had been able to bring an Arcioni apparatus with him from Italy to New York, it was never been accepted by the US patent office (Almansi \& Impastato 1940; Weiner 1988; Shorter \& Healy 2007: 74-76). 


\section{The German Pursuit of an Electroshock Apparatus}

Meanwhile, Bini and Cerletti had introduced their electroshock research results at the III. International Congress for Neurology that was held in Copenhagen in August 1939-only a few days before the German invasion of Poland (Bini 1939; Cerletti \& Bini 1939).

Adolf Bingel (1901-1982), chief physician at the Psychiatric and Mental Hospital of University Erlangen, had attended and was enthusiastic about the possibilities the electroshock apparatus seemed to offer. Still in September 1939, he contacted the head of the electro-medical research laboratory of the Siemens-Reiniger-Werke AG Berlin-Erlangen (SRW or Siemens) in Erlangen, Johannes Pätzold (1907-1980), with the request to construct a device for him. Remarkably, Bingel was not the only congress participant to opt for this approach. The Danish psychiatrist Arild Faurbye (1907-1983) proceeded quite similarly. Upon his return from the Copenhagen Congress Faurbye commissioned a Danish engineer with the reproduction of the Bini model with which he started his first treatments in November 1940 (Kragh 2009).

Similarly, in Erlangen, Bingel did not have to invest much time in persuading the $S R W$ or his medical director and chair of the Erlangen clinic, Friedrich Meggendorfer (1880-1953). On 3 February 1940, Bingel and Meggendorfer could already report on their treatments with an apparatus produced by $S R W$ as "the first German tests" that they had started in December 1939 (Bingel \& Meggendorfer 1940; Lang 2013).

Was it really the political situation that arose from the Pact of Steel that facilitated the fast production of the German apparatus by $S R W$, as Max Müller assumed in his memories? Were the Germans indeed "able to obtain the plans from Arcioni without much ado" (Müller 1982: 247)? Not quite so. In a lecture in June 1940 Meggendorfer explained that it was "only after having overcome some difficulties, the company Siemens-Reiniger was able to make a suitable newly designed apparatus available" (Meggendorfer 1940). "A suitable newly designed apparatus", not just a replica, because the patent right still did prevent to simply make a copy based on the blueprints, and it was after all Bini, and not Arcioni, who owned the Italian patent and had already applied for the acceptance of his patent in the German Reich too.

However, while waiting for his German patent to be granted, Bini approached $S R W$ himself to promote his electroshock construction. The $S R W$, a subsidiary of Siemens \& Halske AG, was considered an important company for the development and production of medical technology products in the German Reich at that time. In this field, $S R W$ ranked among the leading manufacturers in Europe with a pronounced sales network extending to North and South America (Lang 2013: 218). If one wanted to market license rights with sustainable success in Europe's largest and most populated economy, it 
was impossible to sidestep $S R W$. And this applied even more, the more Hitler's aggressive expansion policy proceeded and gained momentum.

The $S R W$ showed extraordinary interest in Bini's promotion of his "electric healing apparatus," telling Bini that they had decided to produce some of his apparatuses on a trial basis and have them subsequently tested to take up "the on-going production and the sales of such healing apparatuses in case of a favourable result" if need be. Yet it was the primary intention of $S R W^{\prime}$ s patent department to get a comprehensive overview "in which countries except for Italy, Germany, France and the United States of America" Bini "had additionally searched for protection for his healing apparatus or had already received it". Therefore, Bini was asked to authorize a patent lawyer appointed by the $S R W$ to learn about the details of the German patent registration. After that, $S R W$ promised to make Bini "a suggestion for an agreement [...] with regard to the usage of your protective rights, regarding the new healing apparatus" which would also regulate the licence fees. ${ }^{9}$ However, in Pätzold's view, the apparatus did not justify any high licence fees since it was possible to build it for a low list price. ${ }^{10}$

\section{German Bypassing of Bini's Patent Application}

While a reconstruction of Bini's Arcioni model was intensively tested as a $S R W$ prototype in patients for its functionality at the same time in corporation with the Psychiatric University Hospital Erlangen by Bingel and Meggendorfer and the mental asylum Eglfing-Haar by Anton Edler von Braunmühl (1901-1957), Pätzold's laboratory collected ideas from the clinical trials so as to change Bini's original construction sufficiently to bypass Bini's still pending patent (cf. more detailed: Lang 2013).

The laboratory received unexpected assistance from the Dutch $S R W$ sales company Almara N. $V$., which reported to $S R W$ that a defect Arcioni apparatus had been delivered to them for repair in mid-January 1940 (Lang 2013: 222). The apparatus was examined by the sales engineers "by every trick in the book" and the result was documented in a precise technical description of the associated circuit diagram and photographic printing from the interior of the apparatus. After the repair, they added the complete documentation to their report, which was subsequently sent to Pätzold via the $S R W$ sales headquarters in Berlin. Unaware of the work conducted in Erlangen, Almara wanted to initiate a respective $S R W$ apparatus using the documentation of the Arcioni construction. In the Netherlands, the interest for this apparatus had grown so much that Almara had already taken precautionary measures by asking the patent law firm Vereenigde Octrooibureaux in Den Haag to inform them if trademarks had been registered by Arcioni in Holland. ${ }^{11}$ 
Meanwhile, the $S R W$ patent department had also searched for a legal way to circumvent Bini's patent registration. An internal memo suggested that a paper from 1922 by Erich Schilf, who at that time had been working as an assistant of the Psychological Institute at Berlin University, had been instrumental in the technical electroshock development (cf. Schilf 1922).

Schilf had caused epileptic seizures by applying periodic short alternating currents through electrodes placed on the conjunctiva of dogs' eyes; the animals immediately became unconscious and were able to bear subsequent seizures without any damage. ${ }^{12}$ According to the patent department, the apparatus later developed by Bini contained "nothing really new" in comparison to Schilf's construction, which is why they came to the conclusion: that "the German patent registration B 188082 VIIIc/21g by Mr. Bini, if it is combated by us, will probably not lead to the assignment of a patent. It is thus not necessary to acquire rights in the German patent registration of Mr. Bini with reference to our fabrication of respective apparatuses."

In doing so, the $S R W$ did not only focus on the national market for later sales. In early 1940, the patent department issued a memo indicating that given the fact that Bini had been granted a patent in Italy, a delivery of "our apparatus" to Italy was "not possible offhandedly." Bini had also applied for a patent in "the USA, England, France and Argentina; however, no patent had been granted in any of those countries so far: For this reason, we are currently not prevented from selling our apparatus also in those countries. All other countries are patent-free."13 SRW had decided to pursue its own electroshock business. The potential licensee had become a competitor Bini could hardly match. ${ }^{14} S R W$ was supported by the National Socialist patent right reform of 1936 that replaced the registration right with the inventor's right. Thus, only the original inventors could claim the patent. ${ }^{15}$ According to the argument of $S R W$ 'S patent department, neither the apparatus nor Bini's electrodes were new "towards the state of technology" and had originally not been developed by him-thus Bini's patent application was obviously contradicting the principles of the new National Socialist patent law.

In May 1940 Kalinowsky wrote to Bini that he was "sorry" to hear that Bini did "encounter the same difficulties with the German patent" as he did "in other countries". Referring to the Pact of Steel, he still wanted "to believe that thanks [!] to the political situation it will be easy to negotiate with Germany" ${ }^{16}$ Kalinowsky's knowledge status was outdated by the technical developments. As early as late June 1940, Pätzold presented the German apparatus in a lecture of the Physikalisch-Medizinische-Sozietät of the University of Erlangen under the name of "Konvulsator". The patent department had chosen the name consciously to distinguish it from the Italian "l'elettroshock." Moreover, Pätzold had changed the construction in a way that Bini's patent-relevant elements had been avoided: the circuit spared the preceding resistant 
measurement and also enabled the direct adjustment of the current in $\mathrm{mA}-$ just as in Walter and Golla's English device (Pätzold 1940).

In reaction to Pätzold's activities, Bini and Cerletti conducted an extremely offensive verbal altercation in the relevant German journals. Claiming that the Italian resistance measurement was necessary to examine "the good preparation of the sick person, the complete performance of electrodes and the absence of short circuits", Cerletti and Bini argued that Pätzold's changes had been done at the cost of security (Cerletti \& Bini 1941: 211).

Interestingly, it was once again the electrode support construction that caused the harshest Italian criticism. In contrast to the Italian electrode clip or forceps (Fig. 2a) "compressing the electrodes maximally together pressing them strongly against the skin", the $S R W$ electrodes were "simply [to] be rested on the head" (Fig. 2b a) — as Bingel and Meggendorfer had proposed and quite similar to the electrode band also already used by Walter and Golla.

Bini and Cerletti claimed that this would result in a higher resistance and provoke the risk that current, following the direction of lower resistance, could get to a place rather distant from the electrodes and possibly damage the heart "to a large and irreversible degree" whereby the effect of electricity could be mortal (Cerletti \& Bini 1941). However, protective devices such as a surge arrester and a cut-off relay had been built into the Konvulsator (Pätzold 1941).

Consequently, Bini and Cerletti were checkmated; Bini's construction was technically neither the only nor the best possible in terms of safety, and Bini was not granted a German patent of his "electric healing device for generating convulsions".

In August 1940 Kalinowsky wrote to Bini from his New York exile and tried to comfort him in his grief about "the sad chapter of patents". Regarding the financial aspect of his commitment towards the introduction of the new
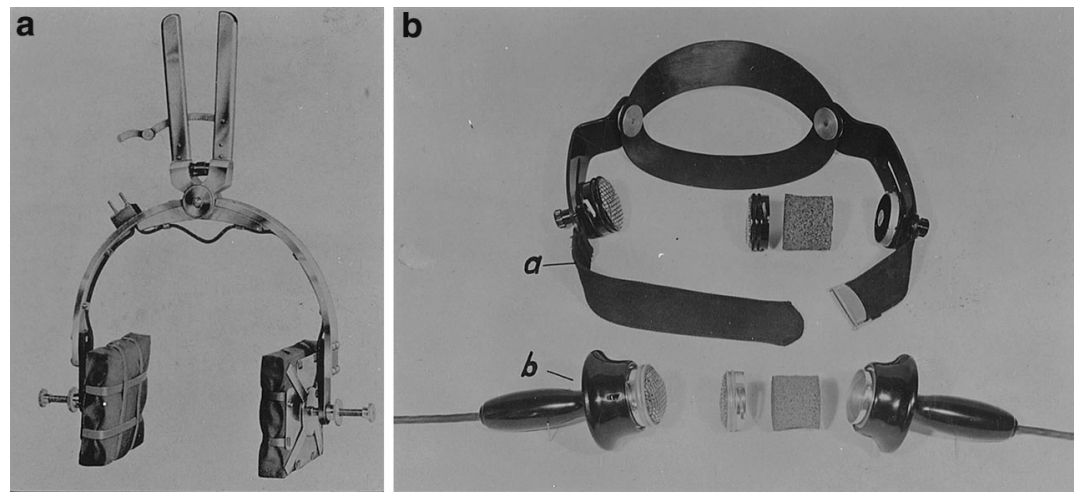

Fig. 2 a Electrode clip of the Arcioni apparatus according to Cerletti and Bini, without date (Siemens MedArchives, Erlangen, Germany). b Electrodes according to Bingel and Meggendorfer (a) and according to Braunmühl (b), without date (Siemens MedArchives, Erlangen, Germany) 
therapy and its apparatus Kalinowsky moreover concluded without any illusions: "Honestly speaking, I am quite sure to never get the money I invested in diverse patents refunded." ${ }^{17}$ In the meantime yet another innovative device series had been developed in Vienna.

\section{The Vienna Elkra Series}

In 1939, the Vienna University Psychiatric Clinic had contracted a talented young physician and graduated technician from Berlin University and had commissioned him to study the Italian electroshock therapy apparatus and to adapt it to the needs of the Vienna clinic (Holzer 1941a).

The "use of electricity in therapy" was one of Wolfgang Holzer's (19061980) major interests. Holzer's technical examination revealed, for example, that the faraidic inductors, which had received dubious fame for their use in the (suggestive) therapy of World War I "War Tremblers", were so badly adjusted that the currents they generated could "by no means be used for organised electrotherapy" (Holzer 1940: 484-485).

Applying his technical knowledge to the matter of convulsive therapy, Holzer developed electroshock devices of different functionalities in collaboration with the Vienna company Reiner $\mathcal{E}$ Co. relying on the Italian and German publications: first Elkra I, a big stand-alone unit with additional electrode holder, and then Elkra II, which attached the entire apparatus directly to the forceps (Fig. 3). Following preliminary animal testing these new devices were studied on patients of the psychiatric Vienna University Hospital (Holzer 1942: 125).

Even clinics that already owned a Konvulsator were especially interested in Elkra II, as it promised to allow electroshock therapy even in the most unsettled patients. However, "due to the war events it was difficult to get such an apparatus" complained Otto Buchner (Buchner 1942: 97), the medical director of a Vienna Clinic that was especially committed to the new psychiatric shock therapies.

After Buchner had directly contacted Holzer to offer his help in the study of the clinical benefits of Elkra II, the clinic received the apparatus, which Holzer introduced during a visit to Buchner's clinic:

The apparatus [Elkra II] itself is the simplest thing you can imagine (see ill.). It consists of a $20 \mathrm{~cm}$-high metal case with the equipment. This is placed on top of a pair of forceps and makes it possible to wedge in the patient's head by keeping it still just as during a forceps delivery. The apparatus can be kept in the doctor's hand and through a button the chronometer in the doctor's hand is pushed. A simple plugging enables the activation of 100 to 150 Volt (Buchner 1942: 98). 
a

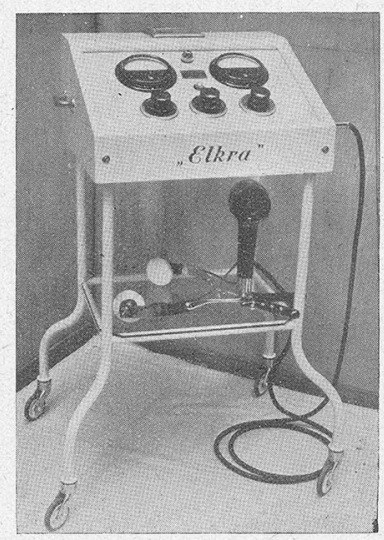

Abb. 2. Elektroschockgerät EL K R A I. Das obere Schalt. pult enthält die Widerstandskontrolleinrichtung, gespeist mit Mittelfrequenz, das Dosisvoltmeter, den Hauptschalter, den Dosierwiderstand, Signallampen und Sicherheitsschaltungen zur Begrenzung von Strom und Zeit. Unter dem Gerät liegt die Elektrodenzange mit der Zeituhr. (Hersteller: F. Reiner u. Co., Wien IX.)

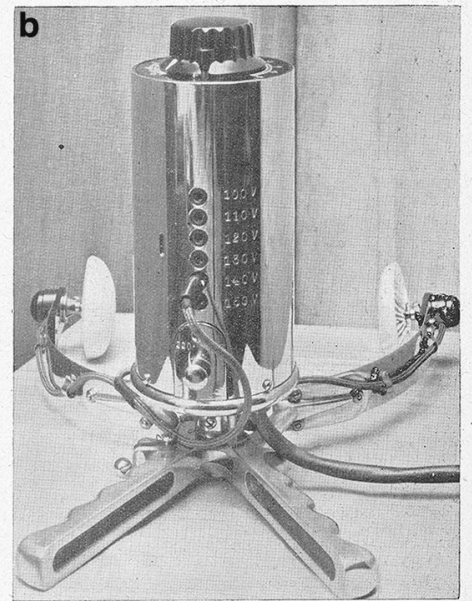

Abb. 3. Elektroschockgerät E L KRA II. Das Gerät besteht aus einer Elektrodenzange, auf welcher Transformator Spannungssdosierung, Zeitschaltuhr und Signallampe aufsebaut sind. Es ist tragbar und wird mittels Stecker an das Lichtnetz angeschlossen. (Hersteller:
F. Reiner u. C o., Wien IX.)

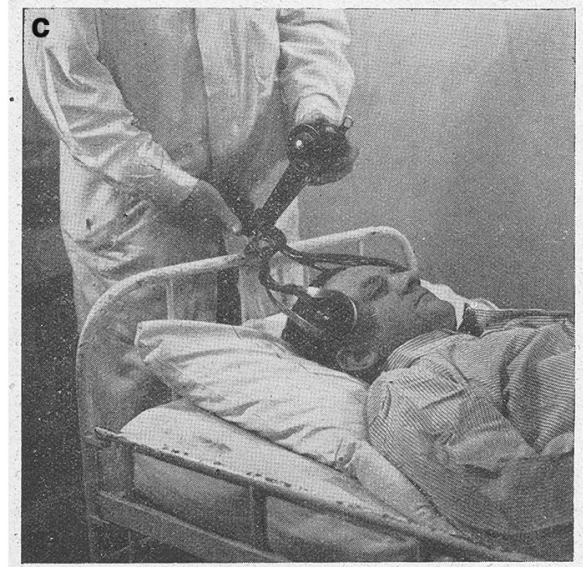

Abb. 4. Das Anlegen der Elektrodenzange des Gerätes E L KR A. I. (Auch das Gerät ELKRA II wird in gleicher. Weise angelegt.)

Fig. 3 Holzer's development series Elkra, and placing the electrode holder with Elkra I and II (Psychiatrisch-Neurologische Wochenschrift 1941 (43), pp. 372, 373 and 378)

His cooperation with Holzer did not, however, prevent Buchner from approaching $S R W$ with the experiences he obtained from working with Elkra II hoping to inspire $S R W$ with his "constant criticism" to absorb the "decisive benefits of the Holzer-apparatus" (Buchner 1942: 98).

Although the circuits of Elkra $I$ and $I I$ were based on the original Italian principle of voltage constancy rather than on the principle of current constancy used by $S R W$ (that is, the voltage was pre-set and not the current 
intensity just like in the Arcioni apparatus), ${ }^{18}$ for Buchner the "decisive benefits" were not in the wiring, but in the arrangements of the electrodes.

Actually, Holzer's careful investigations since late November 1940 had shown hardly any difference between using voltage (V) or current setting $(\mathrm{mA})$. It was the electrode holder construction that made the important difference in the daily clinical practice.

Buchner did not compare the Elkra "electrode forceps" at random to the "delivery forceps" (Buchner 1942: 98)-Holzer himself had explained that in developing them "the lines of an older pair of forceps had simply been cut off and enhanced by elastic steel bands" (Holzer 1941b: 374). Then circular plates had been attached to them to which the terrycloth-coated electrode plates could be affixed for the treatment with metal pins, which were replaceable in the middle.

In clinical routine, these electrode holders proved to be considerably better than electrode appliances attached by means of headbands because the latter "frequently could not even be attached to unsettled patients" (Holzer et al. 1942: 121). Therefore, Holzer had additionally developed another bridge electrode, which was to facilitate a secure application in case of difficult accessibility to the patient from the side (Holzer et al. 1942: 99; Holzer 1942: 127-129).

As far as the electrode forceps and Holzer's bridge electrode were concerned, the regulators were directly attached at the vertex of forceps or bridge to adjust and provide electricity supply. Thus the treating physician was able to position the electrodes at the patient's head and at the same time activate the treatment current without requiring additional staff. This was not possible with Bingel and Meggendorfer's use of the Konvulsator electrodes; as had been critically pointed out not only by Buchner but also empathically by Braunmühl who possessed in Eglfing Haar the largest clinical routine in electroshock therapy in the German Reich. Hence, Braunmühl helped SRW to develop alternative electrodes that were pressed to the patient's head and enabled at the same time the current release (Fig. $2 \mathrm{~b}$ b): Braunmühl's so-called "mobile electroshock therapy technique" (Braunmühl 1942).

Yet the applicability of electroshock therapy depended not only on electrode holder constructions given that obviously the devices required a power supply. Here, Holzer succeeded in constructing a portable device, since his choice of rectangular alternating currency-instead of the previously used sinus-formed alternating current-reduced the necessary amount of current to induce a seizure so considerably that two anode batteries as power sources were sufficient. The result was a portable electroshock device of $8 \mathrm{~kg}$ weight allowing a completely net-independent implementation of electroshock therapy-a substantial practical benefit in clinical application (Holzer 1942: 137-138). In contrast, the Konvulsator II from SRW, available for clinical pre-trials since May 1943, was just a simplified and handy, but not battery-driven device. 


\section{Disputes About Electrode Holder Constructions}

In the case of Elkra II Holzer had opted mostly-just as Cerletti and Bini before-for an electrode forceps, which he made the integral part of the overall device. However neither Holzer nor Reiner $\mathcal{E}$ Co. had considered examining the patent situation of their components for the territory of the German Reich during the development of the apparatus, even though Austria had become officially part of the German Reich with the "Anschluss" (annexation) in 1938. Hence it was ironically $S R W$ who secured a patent for the electrode forceps: the Deutsche Reichspatent (D.R.P.) 578532 for "the forceps form of the anaesthesia device", that stemmed from the product folio of the Munich based company Lotterschmid \& Weinberger (LEW). ${ }^{19}$

In September 1927 Anton Weinberger, an engineer and $L \mathcal{E} W$ shareholder, began his research on electric current pulses, experimenting in particular with the electrical stunning of pigs, assisted by the Munich university veterinarian Max Müller (not to be confused with his psychiatrist namesake from Münsingen). For this purpose $L \mathcal{E} W$ developed "stunning tongs" (Fig. 4a and b). The electrodes of these tongs consisted of "serrated metal plates" that were furnished with "inserted rubber sponges," which were placed at the animals' temples (Kuppelmayr 1930). To allow for an increased conducive performance, the electrodes' sponges were dipped into saltwater before releasing the current by pushing a button at one of the forceps grips. The animal was anesthetized within 15-20 s.

In July 1932 Reiniger, Gebbert E Schall AG Erlangen, a company that would merge with $S R W$ only a couple of months later, entered into a comprehensive sales and supply agreement with $L \mathcal{E} W$. LEW committed to prospectively acquire the entire demand for goods offered by them from the production of $S R W$ that also included the general agency for the entire international sales, except for a few European countries. This also applied to different forms of devices for cattle anaesthesia and their equipment, including an electrode holder type for the electrical anaesthesia of pigs. ${ }^{20}$ In general these products were, however, not sold by the medical engineering brand SiemensReiniger but by the subsidiary Ergos Apparate-Vertriebsgesellschaft m.b.H., Berlin (Ergos) that operated occasionally in Italy as well.

As indicated in the business report by Ergos for 1934, electric anaesthesia did "particularly well in Italy and in the Nordic countries". ${ }^{21}$ The slaughterhouse in Rome, for instance, had equipped itself with the electric anaesthesia by Ergos (Fig. 4c; compare Shorter \& Healy 2007: 36). The technique had already played a role in the development of the Italian apparatus, as Cerletti had advised Bini upon his return from the Swiss Conference on the therapy of schizophrenia in May 1937 to study the safety margin of electrical applications to the head not only on dogs, but also at the slaughterhouse before daring the 

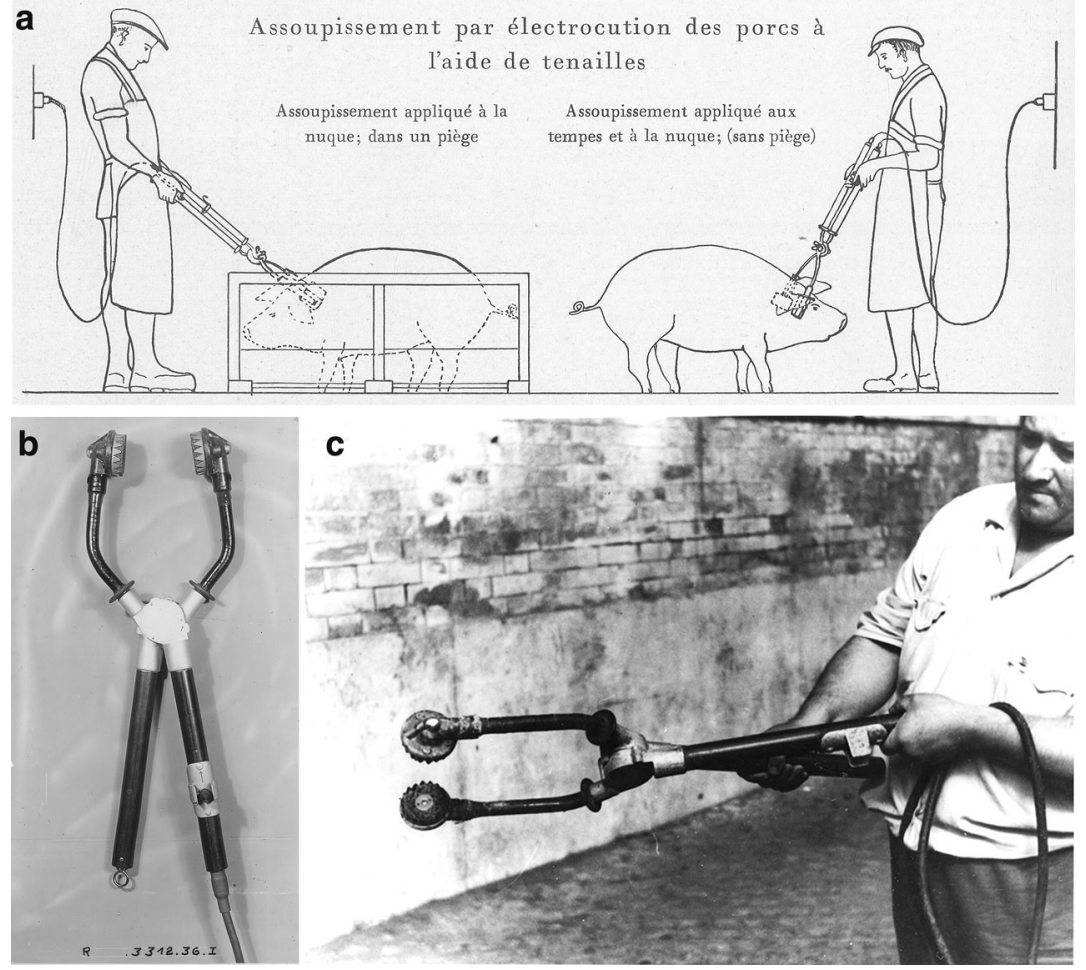

Fig. 4 a lllustration of pig's anaesthesia with the electrode holder (excerpt from a French brochure by Lotterschmidt \& Weinberger, undated, Siemens MedArchives). b Electrode holder for electrical anaesthesia of pigs, Lotterschmid \& Weinberger from the SRW production, 1933. c Electrode holder in the Roman Slaughterhouse, photograph from 1938 (Kansas State Historical Society, Menninger Collection, 118-05-02-13)

first application in man in April 1938 (Accornero 1988: 44; Shorter \& Healy 2007: $36-37) .^{22}$

In $1940 S R W$ decided to use this patent to protect themselves against potential competitors in the new sales area of electroshock therapy. Wolfgang Holzer and Reiner E Co. realized this when SRW turned to Reiner E Co. to assert claims from their patent on the holder electrode of Elkra I and II. Holzer showed deep concern since this affected after all the future marketing and distribution of "his" development. In a letter to the Vienna SRW branch office, Holzer tried to clarify: "In those days, your director [misnomer] Pätzold saw the electrode holder during his visit to my laboratory, neither at that time nor later found a word of objection [...]. After all, it was me who informed your [Mr.] Pätzold at that time about what an electroshock actually was." Above all:

the subordination of electroshock under the broader term anaesthesia and of patients under animals to be slaughtered [...] shall represent a unique curiosity for a leading electromedicine company. It does not apply for the patients in my sphere of influence. ${ }^{23}$ 
However, Holzer's harsh procedure did not detain $S R W$ from insisting on their patent claims. ${ }^{24}$ Given the situation Reiner $\mathcal{E}$ Co. had no choice but to give in finally: after a dispute that lasted several weeks, the company opted for a contractual agreement with SRW. In the document dated 21 March 1941 SRW agreed to give a "simple non-transmittable licence" on the patent to Reiner $\mathcal{E}$ Co. as "registered co-owner" of the D.R.P 578.532, "regarding a 'device for anaesthetizing animals to be slaughtered". ${ }^{25}$ In turn, Reiter $\mathcal{E}$ Co. committed themselves to pay a licence fee for all electroshock devices produced and sold by Reiner E Co. Accordingly, the Swiss company Purtschert finally replaced the electrode forceps in favour of a headband for his device "Psychotron". ${ }^{26}$

One of the reasons that the $S R W$ tried so hard to eliminate the Vienna competitors was that Elkra II was not only more convenient but also much more cost-effective with 390 RM compared to 955 RM for the Konvulsator. As a matter of fact by late June 1941, SRW had sold only fifty Konvulsators, most of them abroad, 23 devices of which were delivered via Almara into the occupied Netherlands. Although at least one device was sold to the Parisian Hopital des Enfants-Malades, other French institutions favoured the Swiss Purtschert $\mathcal{E}$ Co. device (Coffin 2013). Only 18 SRW devices had been sold to psychiatric institutions in the "Großdeutschen Reich," while a couple of mental hospitals had already purchased a Purtschert or an Elkra II device. ${ }^{27}$ Thus the Elkra II or the Purtschert $\mathcal{E}$ Co. apparatus seemed to be the better choice for the future equipment of the mental hospitals of the German Reich.

Aiming to select the best suitable device for the German Reich, the Reich Working Party for Mental Asylums thus tried to evaluate the rivalling models to the Konvulsator, in particular the above-mentioned Purtschert $\mathcal{E}$ Co. device and the Elkra II, in November 1942. Information was mostly obtained from the private Waldhaus clinic in Berlin, which possessed both a Purtschert E Co. apparatus as well as an Elkra II. ${ }^{28}$ Moreover, Meggendorfer in Erlangen was asked for his opinion although he had no experience with either the Elkra II or the Purtschert $\mathcal{E}$ Co. apparatus. He pointed to the vertebral fractures frequently observed elsewhere with the use of the Purtschert $\mathcal{E}$ Co. apparatus, a problem he had not experienced with the Konvulsator. ${ }^{29}$ Notwithstanding that Meggendorfer deemed the Elkra II to be the most cost-effective device, the order went to $S R W$ and their more expensive Konvulsator in late February 1943. ${ }^{30}$ To SRW' S advantage, Meggendorfer had redefined the question of the adequate electroshock therapy device for the German Reich as a problem of vertebral fractures; thus $S R W^{\prime}$ s Konvulsator won the competition, even if it was more than twice as expensive as Holzer's Elkra II. 


\section{Technical Improvisations: Electroshock in Auschwitz and "Euthanasia" Killings}

Clinics that had missed the collective order in spring 1943 were informed by $S R W$ that the delivery period for the electroshock device would be "at least one and a half year". ${ }^{31}$ The simple technical reason for the delay in the delivery process that also concerned the Reich Working Party for Mental Asylums order was that the Konvulsator had been designed for alternating current; yet many clinics did not have any alternating current available since the in-house electricity grid was exclusively supplied with direct current. Therefore, a direct current converter was necessary. Although $S R W$ did not produce this itself, they had promised to include an accessory device in the delivery, although "special converters could not be obtained in the foreseeable future." 32

Considering the supply shortage for medical electroshock technology even in general psychiatric hospitals and asylums shows how much improvisation was necessary to facilitate the use of electroshock therapy in the Auschwitz concentration camp. Although diagnostic label devices as X-ray machines were, for example, available in Auschwitz III, the electroshock apparatus in the working camp of the IG Farben plant in Monowitz was a selfmade machine. Given the conditions of total war, the aim of using electroshock therapy was make mentally ill prisoners fit to work again, or in the words of SS physician Horst Fischer (1916-1966) to "incorporate them again into the working process". 33

The Polish prisoner physicist Zenon Drohocki (1903-1978), was authorized by Chief SS physician at the Auschwitz concentration camp Eduard Wirths (1909-1945) and Horst Fischer to build together with an imprisoned Dutch Philips engineer an electroshock device for the neuropsychiatric department established by Drohocki (1975). Drohocki was trained in neurology and psychiatry, had done research on electroencephalography in Bern, Brussels and Paris as well as acquired practical experience in electroconvulsive therapy in Grenoble (Dirks 2005: 134; annotation 268). During his attempt to flee from occupied France to Switzerland Drohocki had been arrested and deported to Auschwitz. While Drohocki tried to use electroshock also as an anaesthetic method in surgery to make up for the lack of anaesthetics at Monowitz (Drohocki 1975), the SS interest in the method was to exploit human resources in the service of Nationalist community and warfare (Dirks 2005: 140-141).

An even more revealing example of technical improvisation and the flexibility of design in respect of changing social or health-political interests is the fact that a technically modified electroshock device was used in "euthanasia" killings. ${ }^{34}$ During World War II, about 150 inpatients of the mental hospital Gugging and 150 inpatients of the mental hospital Mauer-Öhling were killed between 1943 and 1945 at the hands of the physician Emil Gelny 
(1890-1961) with an Elkra II he had converted himself. Gelny had been appointed as medical director for these both Lower-Austrian mental hospitals in October 1943 (Fürstler \& Malina 2004).

The employees of these hospitals were tried in 1946 at the national court in Vienna and asked among other things how it had technically been possible to use the therapeutic machine for murder. Holzer, the inventor of the original Elkra II, was appointed as an expert at court. ${ }^{35}$

A technical explanation was indeed needed. After all, it had been the declared aim of all the inventors of the electroshock apparatuses to find a construction which would make "accidents and damages with this new method of treatment impossible"; so that even if "the apparatus is used by someone inexperienced or in a bad condition", there would be no damage for the patient or the treating person (Cerletti \& Bini 1941: 212). Notwithstanding Bini's criticism of the $S R W$ apparatus, the Konvulsator also had been praised for its "extensive safeguards disabling any damage of the patient or treatment staff by electric current, as far as possible in human terms" (Stolze 1943: 100).

In order to be able to use the available Elkra II for the quiet continuance of patient murder, Gelny had pins and forks made from metal at the locksmith belonging to Gugging. ${ }^{36}$ Gelny connected the pins to one of the electrodes of the electrode holder from the Elkra II in each case so as to divert the current from each of the two sides in the cable connected to it which branched out at a later point of time. The ends of the diverting cables were connected to the forks just as the ends of the continuing cables. Provisionally wrapped with bandaging material, the forks as substitute electrodes were placed at the hands and feet of the sick person selected for murder. Thus the current was no longer limited to flow among the head electrodes through the brain, as planned for therapeutic use. Through the additional electrode construction, veins, muscles and particularly the heart was streamed from hand to hand and foot-to-foot. Hence death occurred, as Holzer explained to the court, "after the previous electroshock with its known phase of unconsciousness", "due to a combined effect on vital centres and on the heart". 37

Those were anything but "slight" changes in a device that Holzer had by no means developed to "inflict torture" (Friedlander 1995: 169), ${ }^{38}$ but based upon the preliminary Italian works to serve as a modern electro-medical therapy free of the side effects of pharmacological convulsion therapy.

\section{Conclusion}

A material history of electroshock therapy at the level of construction plans, electrodes and patents shows the ways in which the conditions of Fascism, National Socialism and World War II shaped the introduction of electroshock 
in a different perspective than the hitherto prevailing 'histories of ideas', 'social' or 'entangled' histories.

Evidently, the idea of electroshock therapy did not come from the slaughterhouse (cf. Szasz 1971; Kalinowsky 1980). However, within the material history of electroshock therapy and all its technical details, the slaughterhouse story or more exactly the debate about the Deutsche Reichspatent for "the forceps form of the anaesthesia device" for animals to be slaughtered, provides a remarkable example for the recesses of the medical technology business. The transfer of the "anaesthesia electrode forceps" patent from the veterinary technical field to the medical sphere of electroshock therapy enabled $S R W$ to resume a leading position on the European electroshock market.

During the early 1940s, the construction of electroshock devices was remarkably little hindered by national frontiers or the fronts of World War II; it was mostly conditioned by material shortages. Yet, technical improvisation allowed the construction of an electroshock apparatus even in Auschwitz; it even helped its reconstruction as a device for "euthanasia" murder.

Which models were constructed, built, promoted and sold in the German Reich and Europe was historically relative and resulted, for instance, from the forced emigration of Jewish scientists following the Nazi rise to power. Another factor were the changes in patent legislation made by the National Socialists.

The aggravated Italian racial laws following the Pact of Steel in May 1939 had forced, for example, Lothar Kalinowsky to leave the Italian exile; on his further immigration he promoted the technique in silent partnership with its inventor Lucio Bini. Taking the blueprints of Bini's Arcioni device with him on his continued exodus, Kalinowsky encountered more technically talented psychiatrists, especially in England, whose interest in the new research of electroshock made them propose competitive designs. For the German Reich, National Socialist patent legislation facilitated the construction and sale of a German device; Bini's application for a German patent was simply circumvented.

In England, changing the wiring principle of voltage constancy to current constancy proved to be enough modification to the initial construction to enable bypassing prevailing patent law. Sparing the initial resistance measuring simplified the device also to the benefit of lower costs, sometimes sufficient to propose a lower and therefore more attractive sale's prize.

Adapting the make-up of the apparatuses to the changing local conditions of specific clinics or hospitals, as, for example, Holzer did for the Vienna University Clinic or Braunmühl in Eglfing Haar, yielded still further technical solutions including even portable devices.

Differing interest of psychiatrists, industrial companies and mental health politics affected the introduction of the electroshock technique-even at the 
level of screws and wires. The technical variations in electroshock therapy until 1945 were each time a different answer in the quest for the most suited technology for electroshock therapy-be it easy as possible applicability or the extent of side effects, be it the matter of low production and acquisition costs, or even the possible use as a method for "euthanasia". Financial interest of the involved industrial companies was a major reason to challenge the details of the therapeutic technique as the companies searched for alternative techniques primarily to circumvent fees due to protective patent rights. In doing so considerations of business competition outdid clinical medical interests several times.

In this process, the electroshock therapy technique was so adaptable to diverging interests that it was even reversed from a medical therapy into a method of "euthanasia"; an alienation whose possibility is not attributable to the special suitability of electroshock therapy as such, but to the contextual adaptability of every technology.

\section{Acknowledgments}

The authors thank the Unternehmensarchiv für Medizintechnik (Corporate Archive for Medical Technology, cited as Siemens MedArchives, Erlangen, Germany) of the Siemens AG for the access to files, the support during research works and the consent of printing the images. The research was done and the paper written during a position of the corresponding author at the Institute for the History of Medicine at the Charite funded by the joint DFGANR-project "early psychosis" under the direction and coordination of Volker Hess (Berlin) and Nicolas Henckes (Paris).

\section{Endnotes}

1 Archivio Ministerio dell'Industria del Commercio e dell'Artigiabato, Ufficio Italiano Brevetti e Marchi, serie Invenzioni: ,Apparecchio per applicazioni elettriche'/Numero fascicolo 369762 .

2 Ministère du Commerce et de l'Industrie. Direction de la propriété industrielle. Brevet d'Invention $\mathrm{N}^{\circ} 853.520$.

3 Siemens MedArchiv intermediate archive (SMAZ), E-Lab, technical development, direct current and low frequency applications (electroshock) [unsigned, in the following abbreviated E1] Memo Patent Department SRW-Erlangen, 15 February 1940.

4 The guestbook of the mental hospital Münsingen documents Kalinowsky's visit for 6 May 1938; in the archive of Bern, estate Max Müller, there is the letter by Lothar B. Kalinowsky to Max Müller dated 19 March 1939, the authors thank Urs Germann for this reference.

5 Kalinowsky to company Duflot, 11 May 1940, In: Kansas State Historical Society, Menninger Archives Collection, Lucio Bini papers, Kalinowsky correspondence.

6 Kalinowsky to Bini, 26 May 1940, translation from the Italian by the authors. 
7 Ministère du Commerce et de l'Industrie. Direction de la propriété industrielle. Brevet d'Invention $\mathrm{N}^{\circ} 880396$ submitted on 24 March 1942, accepted on 28 Dezember 1942.

8 Kalinowsky to Bini 26 May 1940.

9 Patent deparment SRW-Erlangen to Bini, 9 December 1939, SMAZ, E-Lab, technical development, E1.

10 Memo Pätzold, 6 December 1939, SMAZ, E-Lab, technical development, E1.

11 'Almara' N.V. Amsterdam to SRW-Berlin, 11 January 1940, SMAZ, E-Lab, technical development, E1.

12 Memo Patent department SRW-Erlangen, 15 Ferbuary 1940, SMAZ, E-Lab, technical development, E1.

13 Memo patent department SRW-Erlangen, 15 February 1940, SMAZ, E-Lab, technical development, E1. The $S R W$ had obviously not yet been informed about the acceptance of the patent in France in December 1939; however, the German occupation of France offered the chance to deliver the SRW apparatuses to Paris (cf. Bueltzingsloewen 2010).

14 Although it could not be determined whether SRW had actually had a direct influence within the official patent process, it can be assumed that the SRW patent department would not let their idea related to Bini's patent registration "if we manage to combat it", stand without any deeds. Yet the stock of files from the Reichspatentamt was largely destroyed during World War II or are considered missing. (Cf. introduction/history Reichspatentamt BArch R131, http://www.argus.bundesarchiv.de/R-131-45628/index.htm [10.5.2014]). It must be assumed that among it was also the patent application file B 188 $082 \mathrm{VIIIc} / 21 \mathrm{~g}$ 'Electrical healing apparatus for generating convulsive fits' by Lucio Bini.

15 Reichsgesetzblatt 1936, Teil II, Nr. 16, Berlin 1936, 117-130, $\$ \$ 1-3$; also cf. Reichsgesetzblatt 1877, no. 23, Berlin 1877: 501-510, $\mathbb{2}$ 2. For the National Socialist patent right reform cf. Gispen, Kees 1999. Hintergrund, Bedeutung und Entwicklung der Patentgesetzgebung in Deutschland 1877 bis heute. In: Rudolf Boch (ed.). Patentschutz und Innovation in Geschichte und Gegenwart. Frankfurt/Main: Peter Lang Verlag: 10.

16 Kalinowsky to Bini, 26 May 1940.

17 Kalinowsky to Bini, 13 August 1940.

18 Cf. E-Lab, Notes on the question of current constancy or voltage constancy for the electroconvuslive therapy, 29 November 1941, SMAZ, E-Lab, technical development , E1; cf. also Pätzold, Johannes 1948. 'Technik des Elektrokrampfes'. In: Boris Rajewsky and Michael Schön (eds.) 1948. Biophysics Part II, FIAT Review of German Science 1939-1946. Wiesbaden: Office of Military Government for Germany Verlag: 113.

19 Compilation of protective rights, concerning electrical animal anaesthesia and at which we are entitled, 1 Nov. 1938, SMAZ, E-Lab, technical development, direct current and low frequency use (anaesthesia aparatuses for big animals, aparatuses for the anaesthesia of fish).

20 Reiniger, Gebbert \& Schall to Lotterschmid \& Weinberger, 25 July 1932, ('Lieferabkommen betreffend elektrischer Viehbetäubungs-Apparate, Tötungs-Anlagen, ViehtreibApparate, Zubehör etc.' und 'Vereinbarungen über den Vertrieb elektrischer Viehbetäubungs-Apparate, Tötungs-Anlagen, Viehtreib-Apparate, Zubehör etc.'), Siemens MedArchiv (SMA: 974).

21 Cf. idem; Ergos Apparate-Vertriebsgesellschaft m.b.H., Business report for 1934, 4 March 1935, Siemens MedArchiv (SMA; 1066). 51.

22 Cf. for more detailed version Lara Rzesnitzek and Sascha Lang: Electroshock Therapy in the "Third Reich", forthcoming.

23 Holzer to the SRW-Vienna, 24 Sept. 1941, SMAZ, E-Lab, technical development, E2.

24 Patent department SRW-Erlangen to Holzer, 2 October 1941, SMAZ, E-Lab, technical development, E2.

25 However, a later document of $S R W$ from October 1942 states that the further manufacturing and delivery of the previous execution of the electrode holder by company Reiner $\mathcal{E} C$ o. to which transformer and timer were attached, was forbidden to Reiner $\mathcal{E} C$ o. due to the electrode forceps patent.

26 Contract between SRW and Reiner \& Co. 21 March 1942, E-Lab, technical development E1. Report SRW-Erlangen about a trip to Munich on 7 and 8 October 1941, 10 October 1941, SMAZ, Electromedical laboratory (E-Lab), technical development, direct current and lwo frequency applications (cardiac pacemaker, electrical accidents, resucitation, 
electrical anaesthesia); However, Holzer, in one of his later editions of his book Physikalische Medizin which also contained a section on "electroshock", noted that the company Sanitas from Berlin used a "forceps electrode facility" for their device 'Crampor' since around 1942 (Holzer 1947: 663). Cf: SRW-Erlangen to SRW-Berlin, 20 Oct. 1942, SMAZ, E-Lab, electroshock from 1942.

27 BArch R 96 I-12:50-51.

28 BArch R 96 I-12: 36, 39 and 125.

29 Cf. Meggendorfer to Nitsche, 5 Jan.1943, National Archives at College Park, RG 549, Records of U.S. Army Europe, Judge Advocate Division, War Crimes Branch, Records relating to Medical Experiments, Entry-Number AI 2217, Box 3: $125157 \mathrm{f}$.

30 After seven Konvulsators had been cancelled again by the hospitals by early April, the final order submitted to $S R W$ was corrected to a total of 88 devices (list of ordered SiemensKonvulsatoren, 6 April 1943; Hegener to SRW-Berlin, 9 April 1943, BArch, R 96 no. 12).

31 BArch R 96 I 12: 12.

32 BArch R 96 I 12: 15.

33 Personal record Dr. Horst Fischer dated 14 Aug.1965, cited in Dirks 2005: 137.

34 Cf. for more details in Lara Rzesnitzek and Sascha Lang: Electroshock Therapy in the "Third Reich", forthcoming.

35 Expert opinion by Dr. Wolfgang Holzer, "personally submitted on 23 Aug. 1946” Court A1-VgVr-criminal files: Vg 8eVr681/1955, in it: Vg 8a Vr 455/46).

36 Evidence Anton Aichberger (locksmith in Gugging) before the court Vienna, 3 June 1946, Vg 8a Vr 455/46 (DÖW 18 860/17), compare Danbauer 2012: 82.

37 Report Wolfgang Holzer: 6-8.

38 Friedlander 1995: 169: "a machine designed to give electroshock treatments and thus inflict torture." "Gelny used these machines, with minor adjustments, to kill patients."

\section{References}

Abrams, Richard 1988. Interview with Lothar Kalinowsky, M.D. Convulsive Therapy (4): 24-39. Abrams, Richard 2002. Electroconvulsive Therapy. 4. Aufl. New York: Oxford University Press.

Accornero, Ferdinando 1988. An Eyewitness Account of the Discovery of Electroshock. Convulsive Therapy (4): 40-49.

Almansi, Renato and David Impastato 1940. Electrically Induced Convulsions in the Treatment of Mental Diseases. New York State Journal of Medicine (98): 1315-1316.

Anonymous 1940. Reports of Societies, Electrically Induced Convulsions. British Medical Journal (1/4124): 104-106.

Barnhoorn, Johannes A. J. 1940. Mededeelingen over de toepassing van de convulsietherapie door middel van electroshock. Nederlands tijdschrift voor geneeskunde (84): 290-300.

Berrios, German 1997. The Scientific Origins of Electroconvulsive Therapy: A Conceptual History. History of Psychiatry (8): 105-119.

Bijker, Wiebe E., Thomas P. Hughes and and Trevor J. Pinch (eds.) 1987. The Social Construction of Technological Systems: New Directions in the Sociology and History of Technology. Cambridge, MA: MIT Press.

Bingel, Anton and Friedrich Meggendorfer 1940. Über die ersten deutschen Versuche einer Elektrokrampfbehandlung der Geisteskrankheiten. Psychiatrisch-Neurologische Wochenschrift (42): 41-43.

Bini, Lucio 1939. Der durch elektrischen Strom erzeugte Krampfanfall. In: Knud Winther and Knud H. Krabbe (eds.). III Congrès Neurologique International, Copenhague 21-25 Août 1939, Comptes Rendus des Séances. Kopenhagen: Einar Munksgaard: 706-708.

Braslow, Joel 1997. Mental Ills and Bodily Cures. Psychiatric Treatment in the First Half of the Twentieth Century. Berkely: University of California Press.

Braunmühl, Anton von 1941. Einige grundsätzliche Bemerkungen zur Schock- und Krampfbehandlung der Psychosen. Allgemeine Zeitschrift für Psychiatrie (118): 67-79. 
Braunmühl, Anton von 1942. Über mobile Elektrodentechnik bei der Elektrokrampftherapie. Archiv für Psychiatrie (114): 605-610.

Buchner, Otto 1942. Erfahrungen bei über 1500 Elektroschockfällen. Psychiatrisch-Neurologische Wochenschrift (44): 97-100.

Bueltzingsloewen, Isabelle von 2010. Un fol espoir thérapeutique? L'introduction de l'électrochoc dans les hôpitaux psychiatriques français (1941/1942-1945). Annales historiques de l'électricité (8): 93-104.

Cerletti, Ugo and Lucio Bini 1939. Der Elektroschock in der Neurologie. In: Knud Winther and Knud H. Krabbe (eds.). III Congrès Neurologique International, Copenhague 21-25 Août 1939, Comptes Rendus des Séances. Kopenhagen: Einar Munksgaard: 709.

Cerletti, Ugo and Lucio Bini 1941. Über einige Prinzipien der Anordnung des ersten Elektroschockapparats. Psychiatrisch-Neurologische Wochenschrift (29): 211-215.

Coffin, Jean-Christophe 2013. French Biological Therapeutics in the European Context. In: HansWalter Schmuhl and Volker Roelcke (eds.). "Heroische Therapien"-Die deutsche Psychiatrie im internationalen Vergleich 1918-1945. Göttingen: Wallenstein Verlag: 185-199.

Dirks, Christian 2005. "Die Verbrechen der anderen"-Auschwitz und der Auschwitz-Prozess der DDR: Das Verfahren gegen den KZ-Arzt Dr. Horst Fischer. Paderborn: Schöningh Verlag.

Drohocki, Zenon-byly wiezien obozu koncentracyjnego Oswiecim-Brzezinka-Monowice nr 169779 1975. Wstrzasy elektryczne w rewirze monowickim. Przeglad Lekarski (32): 162-166 [translation Cornelius Borck and Artur Zipf].

Endler, Norman 1988. The Origins of Electroconvulsive Therapy (ECT). Convulsive Therapy (4): $5-23$.

Flemming, Gerald, Frederick Golla and Grey Walter 1939. Electric-Convulsion Therapy of Schizophrenia. Lancet (234): 1353-1355.

Forel, Oscar Luis 1941. L'électrochoc en psychiatrie. Annales Médico-Psychologiques (XV série, 99 année): $32-40$.

Friedlander, Henry 1995. The Origins of Nazi Genocide_From Euthanasia to the Final Solution. Chapel Hill \& London: The University of North Carolina Press.

Fürstler, Gerhard and Peter Malina 2004. Ich tat nur meinen Dienst-Zur Geschichte der Krankenpflege in Österreich in der NS-Zeit. Wien: Facultas.

Grözinger, Michael, Andreas Conca, Jan Di Pauli and Fritz Ramseier 2012. Elektrokonvulsionstherapie: Psychiatrische Fachgesellschaften aus vier Ländern empfehlen einen rechtzeitigen und adäquaten Einsatz. Nervenarzt (83): 919-921.

Golla, Frederick, Grey Walter and Gerald Flemming 1940. Electrically Induced Convulsions. Proceedings of the Royal Society for Medicine (33): 261-267.

Hess, Volker 2000. Der Wohltemperierte Mensch. Fiebermessen in Wissenschaft und Alltag 18501900. Frankfurt/Main \& New York: Campus.

Hess, Volker and Andrew Mendelsohn 2014. Sauvages Paper Work. How Disease Classification Arose from Scholary Note-Taking. Early Science and Medicine (19): 471-503.

Holzer, Wolfgang 1940. Physikalische Medizin in Diagnostik und Therapie. Wien: Verlag Wilhelm Maudrich.

Holzer, Wolfgang 1941. Über die Methodik der Elektroschocktherapie. Allgemeine Zeitschrift für Psychiatrie (118): 357-379.

Holzer, Wolfgang 1941. Einführung in die Methodik der Elektroschocktherapie. Psychiatrischneurologische Wochenschrift (43): 371-381.

Holzer, Wolfgang 1942. Über eine Entwicklungsreihe von Elektroschockgeräten. Allgemeine Zeitschrift für Psychiatrie (121): 124-140.

Holzer, Wolfgang, Anna Klaue and Herbert Reisner 1942. Erfahrungen mit der Elektroschocktherapie. Allgemeine Zeitschrift für Psychiatrie (120): 119-145.

Kalinowsky, Lothar 1977. Lothar B. Kalinowsky. In: Ludwig J. Pongratz (ed.). Psychiatrie in Selbstdarstellungen. Bern: Verlag Hans Huber: 147-164.

Kalinowsky, Lothar 1980. The Discoveries of Somatic Treatments in Psychiatry: Facts and Myths. Comprehensive Psychiatry (21): 428-435.

Kalinowsky, Lothar 1986. History of Convulsive Therapy. Annals of the New York Academy of Sciences (462): 1-4.

Kragh, Jesper V. 2009. The Origins of Electroconvulsive Therapy in Denmark. Journal of ECT (25): 270-273. 
Kuppelmayr, Hans 1930. Die elektrische Betäubung bei Schweinen. Zeitschrift für Fleisch- und Milchhygiene (40): 452-453.

Lang, Sascha 2013. Psychiatrie, technische Innovation und Industrie. Die Siemens-Reiniger-Werke und die Entwicklung des Elektrokrampftherapiegerätes Konvulsator im Zweiten Weltkrieg. In: Hans-Walter Schmuhl and Volker Roelcke (eds.). "Heroische Therapien"-Die deutsche Psychiatrie im internationalen Vergleich 1918-1945. Göttingen: Wallenstein Verlag: 223229.

Stolze, Heinrich 1943. Die technische Durchführung der Elektrokrampfbehandlung mit dem Konvulsator von Siemens. Psychiatrisch-neurologische Wochenschrift (45): 100.

Lapipe, Marcel and Jean Rondepierre 1941. Essais d'un appareil français pour l'électro-choc. Annales Médico-Psychologiques (XV série, 99 année): 87-95.

Meduna, Ladislav 1937. Die Konvulsionstherapie der Schizophrenie. Halle: Carl Marhold.

Meggendorfer, Friedrich 1940. Elektrokrampfbehandlung der Psychosen. Deutsche Medizinische Wochenschrift (42): 1155-1157.

Müller, Max 1982. Erinnerungen. Erlebte Psychiatriegeschichte 1920-1960. Berlin: SpringerVerlag.

Pätzold, Johannes 1940. Das Gerät zur Elektrokrampferzeugung und seine physikalischen Grundlagen. Deutsche Medizinische Wochenschrift (42): 1157-1160.

Pätzold, Johannes 1941. Bemerkungen zum Aufsatz von Prof. Dr, U. Cerletti und Dr. L. Bini, Rom: "Über einige Prinzipien der Anordnung des ersten Elektroschockapparats". PsychiatrischNeurologische Wochenschrift (29): 287-290.

Peters, Uwe Hendrik 1992. Die Einführung der Schockbehandlungen und die psychiatrische Emigration. Fortschritte der Neurologie und Psychiatrie (60): 356-365.

Porter, Roy 1985. The Patient's View: Doing Medical History from Below. Theory and Society (14): $175-198$.

Reil, Johann Christian 1808. Über den Begriff der Medicin und ihre Verzweigungen besonders in Beziehung auf die Berichtigung der Topik der Psychiaterie. In: Johann Christian Reil and Johann Christian Hoffbauer (eds.). Beyträge zur Beförderung einer Curmethode auf psychischem Wege. Bd. 1. Halle: Curtsche Buchhandlung: 161-279.

Rzesnitzek, Lara 2013. Lothar B. Kalinowsky und die Einführung der Elektrokrampftherapie in Europa. Die verflochtene Geschichte eines "zufälligen” Aufbruchs "wider Willen"? In: HansWalter Schmuhl and Volker Roelcke (eds.). "Heroische Therapien"-Die deutsche Psychiatrie im internationalen Vergleich 1918-1945. Göttingen: Wallenstein Verlag: 200-215.

Rzesnitzek, Lara 2015a. A Berlin Psychiatrist with an American Passport: Lothar Kalinowsky, Electroconvulsive Therapy and International Exchange in the Mid-Twentieth Century. History of Psychiatry (26): 433-451.

Rzesnitzek, Lara 2015b. "Schocktherapien" und Psychochirurgie in der frühen DDR. Nervenarzt (86): 1412-1419.

Sakel, Manfred 1935. Neue Behandlungsmethode der Schizophrenie. Wien: Perles.

Schilf, Erich 1922. Über experimentelle Erzeugung epileptischer Anfälle durch dosierte Starkstromenergie. Einfluß von Maßnahmen pharmakologischer, chirurgischer und serologischer Art auf die künstlich erzeugte Epilepsie. Zeitschrift für experimentelle Medizin (28): 127-143.

Schmuhl, Hans-Walter and Volker Roelcke 2013. Einleitung. In: Hans-Walter Schmuhl and Volker Roelcke (eds.). "Heroische Therapien"-Die deutsche Psychiatrie im internationalen Vergleich 1918-1945. Göttingen: Wallenstein Verlag: 9-28.

Selzer 1939. Cerletti e Bini: L'elettroshock. Zentralblatt für die gesamte Neurologie und Psychiatrie, Referateteil (93): 486.

Shepley, William H. and James S. McGregor 1939. Electrically Induced Convulsions in the Treatment of Mental Disorders. British Medical Journal (2/4121): 1269-1271.

Shorter, Edward and David Healy 2007. Shock Therapy: A History of Electroconvulsive Treatment in Mental Illness. New Brunswick, NJ: Rutgers University Press.

Siemen, Hans-Ludwig 1999. Psychiatrie im Nationalsozialismus. In: Michael von Cranach (ed.). Psychiatrie im Nationalsozialismus: die bayerischen Heil- und Pflegeanstalten zwischen 1933 und 1945. München: Verlag Oldenbourg: 15-34.

Sogliani, Giorgio 1939. Eine neue Methode der Krampftherapie: die Elektroshocktherapie. Erste Ergebnisse. Deutsche Zeitschrift für Nervenheilkunde (149): 159-168.

Szasz, Thomas 1971. From The Slaughterhouse to the Madhouse. Psychotherapy (8): 64-67. 
A Material History of Electroshock Therapy

de Valk, Melissa 2009. Heterfgoed van de elektroshocktherapie in Nederland, 1939-1975. PhD Thesis, Univ. of Utrecht.

Weiner, Richard D. 1988. The First ECT Devices. Convulsive Therapy (4): 50-61.

\section{Lara Rzesnitzek}

Institut für Geschichte der Medizin und Ethik in

der Medizin der Charité

Thielallee 71

14195 Berlin

Germany

E-Mail: lara.rzesnitzek@charite.de

Sascha Lang

Schmiedgasse 2

86853 Langerringen

Germany

E-Mail: lang_sascha@web.de 